\title{
Impact of multiple stressors on sea bed fauna in a warming Arctic
}

\author{
Lis L. Jørgensen ${ }^{1, *}$, Raul Primicerio² ${ }^{2}$ Randi B. Ingvaldsen', Maria Fossheim ${ }^{1}$, \\ Natalia Strelkova ${ }^{3}$, Trude H. Thangstad ${ }^{1}$, Igor Manushin ${ }^{3}$, Denis Zakharov ${ }^{3}$ \\ ${ }^{1}$ Institute of Marine Research, 9294 Tromsø, Norway \\ ${ }^{2}$ University of Tromsø - The Arctic University of Norway, 9037 Tromsø, Norway \\ ${ }^{3}$ Knipovich Polar Research Institute of Marine Fisheries and Oceanography, 183038 Murmansk, Russia
}

\begin{abstract}
The Arctic Barents Sea is experiencing a record temperature increase, a poleward shift in the distributions of commercial fish stocks, and invasion by the snow crab, a new predator. To evaluate benthic community vulnerability when exposed to seawater warming, bottom trawling, and predation from a new predator, we used a trait-based approach and applied this to an extensive dataset of $>450$ megabenthic taxa, from a 1.5 million $\mathrm{km}^{2}$ area. Taxon rank values were obtained after sorting the taxa by temperature median and temperature range, i.e. the temperature sensitivity trait, and by body height, mean weight, and mobility, i.e. the trawl vulnerability trait, and were given as a size-based prey classification, i.e. the predation trait. The taxon rank values were then used to calculate the mean community sensitivity. Our study showed a recent significant increase in community mean temperature ranks, indicating an increased importance of species with affinity for warmer waters and a reduced importance of coldwater species. Commercial fish stocks and snow crabs are expanding into the western part of the Barents Sea, thereby simultaneously increasing the exposure of large immobile species to trawling and of small prey species to crab predation. Overall, we found a high level of vulnerability to the 3 investigated stressors in the northwestern Barents Sea, which may lead to alterations in community structure and diversity. Mapping vulnerability to multiple stressors enables authorities managing human activities to identify vulnerable areas that warrant special measures, including protection from trawling and reduction of the snow crab stock.
\end{abstract}

${ }^{*}$ Corresponding author: lis.lindal.joergensen@imr.no

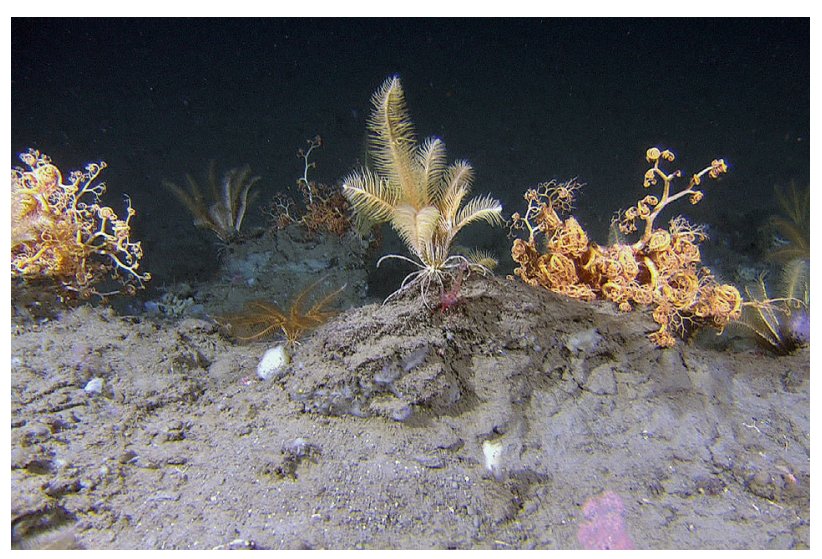

Individuals of a benthic community in the Arctic Barents Sea that are easily damaged by a bottom trawl.

Photo: Mareano, IMR

KEY WORDS: Climate warming $\cdot$ Sea ice reduction . Trawling · Snow crab invasion . Megabenthos . Sensitivity · Vulnerable species

\section{INTRODUCTION}

Climate warming is a major threat to biodiversity and the functioning of marine ecosystems (Sunday et al. 2012), and can alter population ecology of native species, changing geographic ranges and the structure and composition of communities (Walther et al. 2002, Doney et al. 2012). Local environmental stres-

(C) The authors 2019. Open Access under Creative Commons by Attribution Licence. Use, distribution and reproduction are unrestricted. Authors and original publication must be credited. 
sors may exacerbate the impact of global environmental change on species and ecosystems (Crain et al. 2008). The resulting impact on faunal communities will depend on the sensitivities of member species to the combination of environmental stressors. Presently, the combined impact of seawater warming and other stressors on Arctic marine communities is not known (but see Kenny et al. 2018 for the North Sea). The effects of climate change are particularly severe in the Arctic, where seawater warming and associated predicted species invasion rates are respectively twice (Hoegh-Guldberg \& Bruno 2010) and 5 times (Cheung et al. 2009) the global average.

The Arctic Barents Sea is currently experiencing rapid seawater warming. Over the last 4 decades, the late summer temperature has increased by almost $1.5^{\circ} \mathrm{C}$ (Lind \& Ingvaldsen 2012), the ice cover has decreased by $10 \%$ (Årthun et al. 2012), and the area of Atlantic Water has increased substantially (Johannesen et al. 2012 and Fig. S1 in the Supplement at www.int-res.com/articles/suppl/m608p001_supp.pdf), associated with northward shifts in the frontal zone where Atlantic and Arctic water masses meet (the Polar Front) (Oziel et al. 2016). Temperature increase accelerated after the year 2000, with a sudden, rapid warming taking place throughout the entire water column (Lind et al. 2018). Temperature observations from the southern Barents Sea (Russian Kola section) show that the year 2012 was the warmest on record, and the third highest mean value since 1900 was recorded in 2015 (Larsen et al. 2015). The northern Barents Sea is experiencing the strongest declines in winter sea ice concentration and the most rapid surface warming in the entire Arctic, and may soon complete the transition from a cold and stratified Arctic to a warm and well-mixed Atlantic-dominated climate regime (Lind et al. 2018).

In the Barents Sea, climate warming has led to poleward shifts in fish communities (Fossheim et al. 2015) and caused a restructuring of the Arctic ecosystem for plankton, fish, benthos, sea birds, and marine mammals (Kortsch et al. 2015, Frainer et al. 2017). Commercial fishing activity in the Barents Sea (Shevelev et al. 2011) occurs most intensively on the shelf along the western Barents Sea (Fig. S2), the southern Barents Sea, and the area around Bear Island on the Spitsbergen and Central Bank (Misund et al. 2016). High trawling activity has also been recorded in the central parts of the Russian Barents Sea and along the archipelago of Novaya Zemlya, whereas trawling activity is very low in the northeastern part of the Barents Sea (Lyubin et al. 2011) and in seasonally ice-covered areas in the north. However, when perennial sea ice retracts and commercially important fish stocks shift poleward (Kjesbu et al. 2014, Landa et al. 2014), fisheries may expand into areas previously unaffected by bottom trawling.

The Barents Sea is also experiencing a simultaneous increase in abundance of the invasive snow crab Chionoecetes opilio (>3000 ind. $\mathrm{km}^{-2}$ ). In 1996, the first snow crab was identified on Goose Bank in the southeastern part of the Barents Sea. Since then, the number of crabs has increased steadily from 0.6 million individuals across $44000 \mathrm{~km}^{2}$ in 2004 to more than 2280 million across $662000 \mathrm{~km}^{2}$ in 2013, primarily spreading westward (Pavlov \& Sokolov 2003, Bakanev et al. 2016, Strelkova 2016, see also Fig. S3), and snow crab juveniles were first recorded northeast of Svalbard in August 2017 (L. L. Jørgensen pers. obs.). The snow crab has an optimal temperature preference of -1.5 to $3.0^{\circ} \mathrm{C}$ (Bakanev 2015). Climate warming will determine the future spread of the nonnative snow crab in the Barents Sea (Pavlov \& Sokolov 2003, Bakanev 2015), and a future crab fishery is expected to develop around Svalbard (Hansen 2016). The snow crab is a benthic predator (Squires \& Dawe 2003), with a mean annual consumption rate of $4.6 \mathrm{~g}$ of benthic prey per $\mathrm{m}^{2}$ (Manushin et al. 2016), that might reduce biodiversity (Hansen 2016) and compete with other bottom-feeding species (Kortsch et al. 2015).

The Barents Sea benthic megafaunal (invertebrate bottom-dwelling animals larger than $4 \mathrm{~mm}$ ) communities are currently experiencing rapid seawater warming, with a record temperature increase (Lind \& Ingvaldsen 2012, Smedsrud et al. 2013), concurrent with increased trawling (Misund et al. 2016) and predator invasion (Strelkova 2016). This part of the benthic fauna displays clear biogeographic patterns, with a productive Arctic community prevailing in the northeast (Degen et al. 2016), and an Atlantic warmwater community in the southwest (Jørgensen et al. 2015, Johannesen et al. 2017). A deep, coldwater community is found in the northwestern Barents Sea, whereas a shallow-bank community prevails in the southeastern Barents Sea, on the Spitsbergen Bank south of Svalbard, and sporadically west and north of Svalbard (Jørgensen et al. 2015). This strong spatial variability in taxonomic composition is expected to be associated with variation in phenotypic traits due to adaptation and environmental filtering along latitudinal and climatic gradients (Marshall et al. 2012, Marshall \& Burgess 2015). In general, temperature tolerance will determine species sensitivity to climate warming, whereas morphology, behaviour, and life history traits will affect species' sen- 
sitivity to other stressors associated with seawater warming, such as new harvesting regimes and invasive predators.

Here we identify geographical areas of possible ecological change in the benthic megafauna community when exposed to seawater warming, bottom trawling, and predation from the newly arrived snow crab. We used a trait-based approach to characterize the sensitivity of different benthic invertebrate taxa when exposed to seawater warming, trawling, and snow crab predation by (1) investigating the community sensitivity to sea water warming from 2009-2011 to 2012-2015, (2) calculating the unweighted and weighted (biomass) community vulnerability to bottom trawling, and (3) calculating the community proportion of snow crab prey in terms of species and for biomass.

\section{MATERIALS AND METHODS}

\subsection{Study area}

The Barents Sea is one of the continental shelf areas surrounding the Arctic Ocean. It covers an area of $\sim 1.6$ million $\mathrm{km}^{2}$, with an average depth of $230 \mathrm{~m}$ (Fig. 1; Jakobsson et al. 2004), and is characterized by a transitional zone from Atlantic to Arctic water masses. There are several bank areas with depths between 50 and $200 \mathrm{~m}$, and basins and trenches down to the maximum depth of about $500 \mathrm{~m}$ at the western boundary. Relatively warm $\left(2-8^{\circ} \mathrm{C}\right)$ Atlantic Water of the Norwegian Atlantic Current and coastal

Fig. 1. Barents Sea, showing (a) bathymetry and local names, and (b) the 2280 stations (black dots) sampled during 2009-2015. The white lines in both panels delimit the Norwegian and Russian Economic Zones, whereas the triangle in the central part of the map represents international waters (high seas)
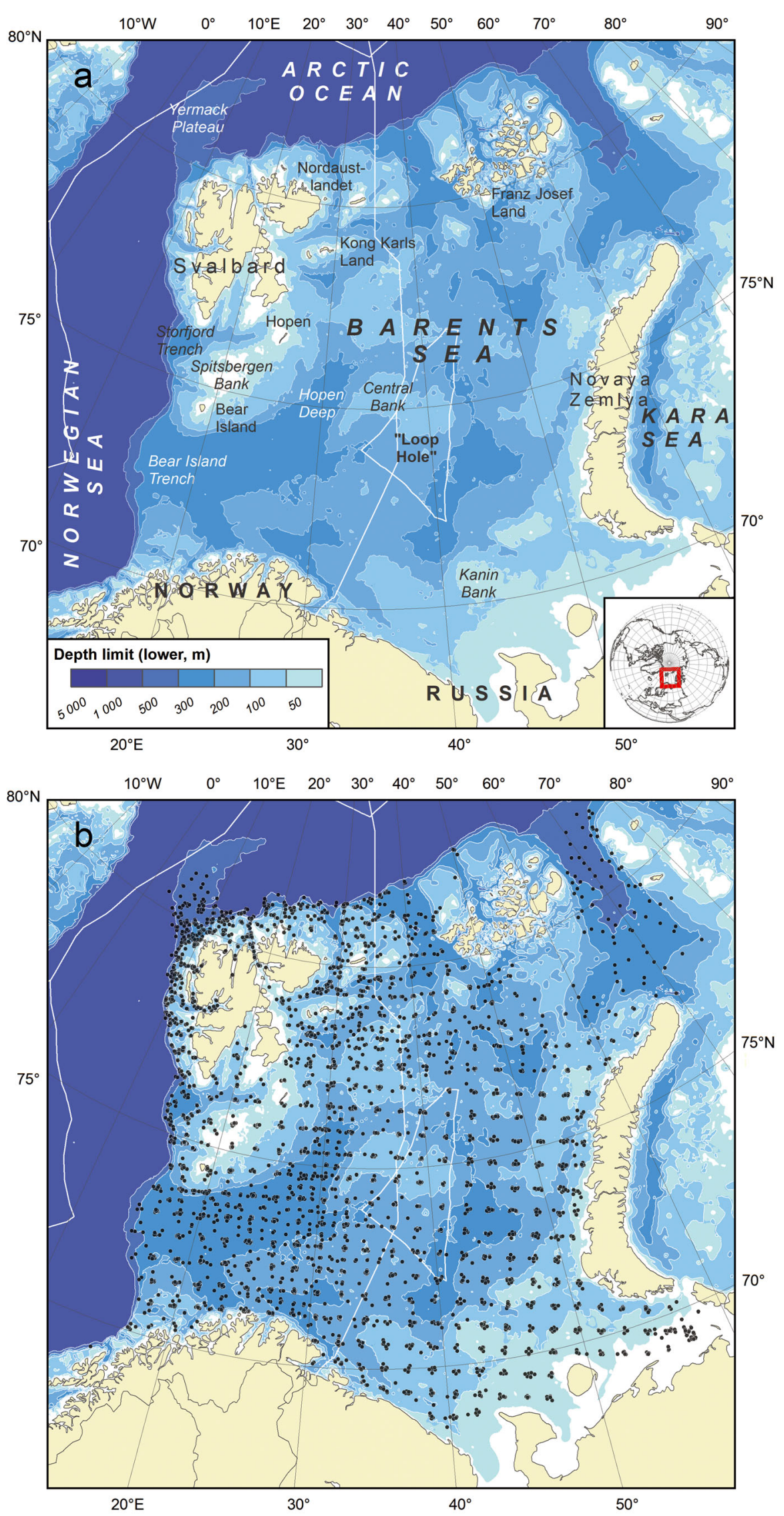
waters of the Norwegian Coastal Current flow into the Barents Sea from the southwest (Loeng 1991). These currents are the main source of heat input to the region and keep the southern Barents Sea relatively warm and ice-free. Colder Arctic water (temperatures below $0{ }^{\circ} \mathrm{C}$ ) dominates in the northern Barents Sea. The border area between the Atlantic and Arctic water masses forms the oceanographic Polar Front. Atlantic water also enters the northern Barents Sea from the north in deeper areas between Svalbard and Franz Josef Land (Lind \& Ingvaldsen 2012). The northern parts of the Barents Sea are seasonally icecovered, with maximum ice coverage in March-April and minimum ice coverage in August-September (Loeng 1991).

\subsection{Data collection and processing}

Data were obtained from the joint Institute of Marine Research (IMR, Norway) and Knipovich Polar Research Institute of Marine Fisheries and Oceanography (PINRO, Russia) Barents Sea Ecosystem Survey (Michalsen et al. 2013). Sampling was done in August-September of each year from 2009-2015. Sampling stations were at fixed positions along a regular grid (36 nautical miles [n miles], $65 \mathrm{~km}$ ) between each station) in the central Barents Sea, whereas the steep continental slope west and north of Svalbard had a depth-stratified approach. The whole sampling area spanned approximately 1.5 million $\mathrm{km}^{2}$ (Fig. 1). The trawling depth, registered by depth sensors on the trawl for each bottom trawl station, varied from $15 \mathrm{~m}$ to a maximum of $1000 \mathrm{~m}$, limited by the wire length. Due to sea ice cover, the most remote northern areas were not sampled each year by this annual survey.

\subsubsection{Temperature}

Bottom-water temperatures were taken at all stations each year, at the deepest sample ( $5 \mathrm{~m}$ above the seabed) from vertical casts made with a Seabird CTD. The CTD casts were usually performed at the same locations as the bottom trawling; when this was not the case, the closest CTD station was used to represent the trawling station (Fig. S1).

\subsubsection{Benthos sampling}

A total of 2280 stations were sampled (Fig. 1b): 1051 stations during the colder period of 2009-2011, and 1230 stations during the record warm period of 2012-2015. The total sampled biomass of benthic megafauna was almost $70 \mathrm{t}$, encompassing over 4.4 million individuals. Some species were pooled to genus or higher taxonomic levels because of uncertain species identification. The final list included 447 taxa (of which 263 were identified to species level).

Samples were taken with a Campelen 1800 bottom trawl, rigged with rockhopper ground gear and towed on double warps, and standardized to a fixed sampling effort of $15 \mathrm{~min}$ (equivalent to a towing distance of $0.75 \mathrm{n}$ miles $[\sim 1.4 \mathrm{~km}])$. The horizontal opening of this trawl is $17 \mathrm{~m}$, and the vertical opening is $4 \mathrm{~m}$ (Engås \& Ona 1990). The mesh size is $80 \mathrm{~mm}$ (stretched) in the front and $24 \mathrm{~mm}$ at the codend, allowing the capture and retention of small fish and the largest benthos (benthic megafauna larger than $4 \mathrm{~mm}$ ) from the seabed.

The benthic megafauna was identified to the lowest possible taxonomic level, counted, and the wet weight measured onboard the vessel, in accordance with standard procedures (Jørgensen et al. 2015). The length of the largest individuals per taxon in the Barents Sea was measured (to the nearest $\mathrm{cm}$ ) in the body direction that reflected the vertical distance from the top of the animal to the sea bed. For example, the large sea star Solaster syrtensis (170 g mean body weight) measures only $5 \mathrm{~cm}$ from the top of the animal to the seabed, whereas the sea pen Umbellula encrinus (39.6 g mean body weight) can reach heights of $>200 \mathrm{~cm}$ from the top of the animal to the peduncle in the seabed (see also Table S1). In cases where taxa represented a large group of species (e.g. Porifera, Bryozoa, Hydroida), mean size and weight were chosen as representative for the group. Here we considered a trawl catch of benthic megafaunal taxa to sample a 'community'.

\subsection{Trait-based sensitivity and vulnerability estimates}

The response traits were chosen and grouped according to the specific stressor they were intended to address, that is water temperature, bottom trawling, or snow crab predation (see Table S1 and description below). Mean community sensitivity and vulnerability estimates were calculated for each cell $(36 \times$ $36 \mathrm{n}$ miles) of a predefined grid. All taxa were used in the analyses, including those pooled to genus or higher taxonomic levels. In the case of identification to species level (263 species), the mean community measures were considered to be precise, whereas in cases where a higher taxonomic level was used 
(147 taxa), we considered individual members of the taxon to be phenotypically similar and provided averaged, approximate estimates of trait values. When using high taxonomic levels (34 taxa) as in the case of sponges, bryozoans, and hydroids, the members of the taxon were assumed to be morphologically similar, but potentially different in terms of thermal niche. A summary of the 2 datasets, i.e. with and without large groups, showed a strong correlation $\left(R^{2}=0.875\right)$, and the large groups were therefore included in all analyses.

\subsubsection{Climate warming}

In climate studies addressing the spatial distribution of species and their sensitivity to warming, it is common to use a species temperature index (STI), i.e. the average temperature experienced by individuals of a species over the species' distribution range, which is the simplest parameter of the species climate envelope (Thuiller et al. 2005). More recently, community temperature indices (CTI) have been proposed to address the temperature sensitivity of a whole community or assemblage (Devictor et al. 2008).

Here, we computed STI and CTI for Barents Sea benthos, focussing on rank values as the basis for our indices of temperature sensitivity. Our STIs are not calculated on the full distributional range of species, but are based on Barents Sea bottom water temperature and benthic taxa distribution, sampled annually in August-September, from 2009 to 2015, i.e. the realised, and not the true full, distribution range. Our STI is modified from previous work, as we relied on median, rather than mean, temperatures. Further, to obtain a temperature sensitivity rank-value for each taxon, taxa were sorted according to the combination of their STI (50th percentile) and temperature range (10th-90th percentile range), thereby providing values ranking species from cold, stenothermal to cool, eurythermal (see Table S1).

The above taxon-specific sensitivity rank values were used to compute a community mean rank for each station based on the taxonomic composition at that station. The resulting mean rank value was then averaged across the stations pertaining to a given grid cell, and mapped to help evaluate the spatial community temperature sensitivity during 2 periods (2009-2011 and 2012-2015). These periods were chosen based on the recent hydrographic changes in the Barents Sea, with the most recent 4 years (20122015) denoted as record warm by Larsen et al. (2015), registering a strong reduction of the area of Arctic water (temperature $<0^{\circ} \mathrm{C}$ ) in the central Barents Sea, and a substantial warming of water in the Hopen Deep and the area east of Svalbard (Lind et al. 2018).

To produce a 'hotspot' map of changes in the Barents Sea, the differences in the mean community sensitivity value from 2012-2015 to 2009-2011 were plotted for grids for which values for both periods were available. Increased (community warming) and decreased (community cooling) values were depicted as a circle in the centre of grids and reflect the degree of change.

Due to the expected poleward expansion of cool, eurythermal taxa and reduced importance of cold, stenothermal taxa, we tested whether there had been a recent decrease in temperature sensitivity of benthic communities in the Barents Sea. For this, we used a generalized least squares (GLS) model. To account for spatial variability in community sensitivity in the model, a rectangular grid of 9 equally sized areas (blocks), each area encompassing 35 grid cells (Fig. S4.3), was specified and included as a factor in the model. The difference in mean community temperature sensitivity between periods was then tested, having corrected for spatial autocorrelation using a continuous autoregressive, AR (1), correlation structure (CAR), relying on longitude and latitude of individual grid cells.

Areas in the Barents Sea inhabited by communities dominated by cold, stenothermal species (herein called Arctic communities) were defined as vulnerable toward seawater warming, whereas areas inhabited by communities of cool, eurythermal species (called boreal communities) were defined as robust.

\subsubsection{Trawling}

Body size (Jennings et al. 2001a,b, Duplisea et al. 2002, Shin et al. 2005), morphology, and mobility (Certain et al. 2015, Jørgensen et al. 2016) of a given taxon affect its vulnerability to trawling as they determine the probability of its being caught and/or entangled by a trawl, i.e. its exposure, as well as the probability and severity of damage inflicted by a trawl, i.e. the taxon's sensitivity. To obtain a rankvalue of vulnerability to trawling per taxon, all taxa were sorted according to their

(1) maximum height above the seabed as recorded in the Barents Sea,

(2) mean body mass as recorded for the Barents Sea (biomass/numbers of individuals), and

(3) mobility (3 categories: 'sessile', 'speed of a snail', 'speed of a crab') (see Table S1). 
These taxon-specific rank values were used to calculate the unweighted and weighted (taxa biomass/ community biomass $) \times($ taxa specific trait value) mean community vulnerability. The resulting community vulnerability estimates were calculated for each grid cell by allocating sampling stations to the grid cell and averaging across years (2009-2015).

An area in the Barents Sea with communities dominated by the highest, largest, sessile taxa is defined as vulnerable to trawling, whereas an area with a community dominated by low, small, fast-moving taxa is defined as robust to trawling.

\subsubsection{Snow crab predation}

Snow crabs in the Barents Sea primarily feed on Crustacea, Polychaeta, Echinodermata, and Mollusca (Manushin et al. 2016). In the present study, snow crabs were identified as potential predators on 82 of the 467 taxa (see Table S1). Community sensitivity to predation was determined as the (1) relative number of prey species/taxa per trawl haul, and (2) relative prey biomass per trawl haul averaged across years within grid cells.

The sorting of trait tables for ranking and computations was conducted in Excel 2016 and in $\mathrm{R}$ version 3.2 (R Development Core Team 2008), the GLS statistical modelling was performed in R with package 'nlme', and maps were produced in ArcGIS version 10.1. A full list of the species, coded for climate, trawl, and prey sensitivity, is available in Table S1.

\section{RESULTS}

\subsection{Abundance, biomass, and diversity of benthic megafauna}

The total biomass of benthic megafauna was highest in the southwest, along the west coast of Novaya Zemlya, on the bank areas of the central Barents Sea, and west of Svalbard
(Fig. 2a). The biomass of megafauna in the central and southeastern part of the Barents Sea was generally low (<1.5 kg per $15 \mathrm{~min}$ trawl). The total number of individuals was highest in the northeastern area of the Barents Sea, including south of Novaya Zemlya, in

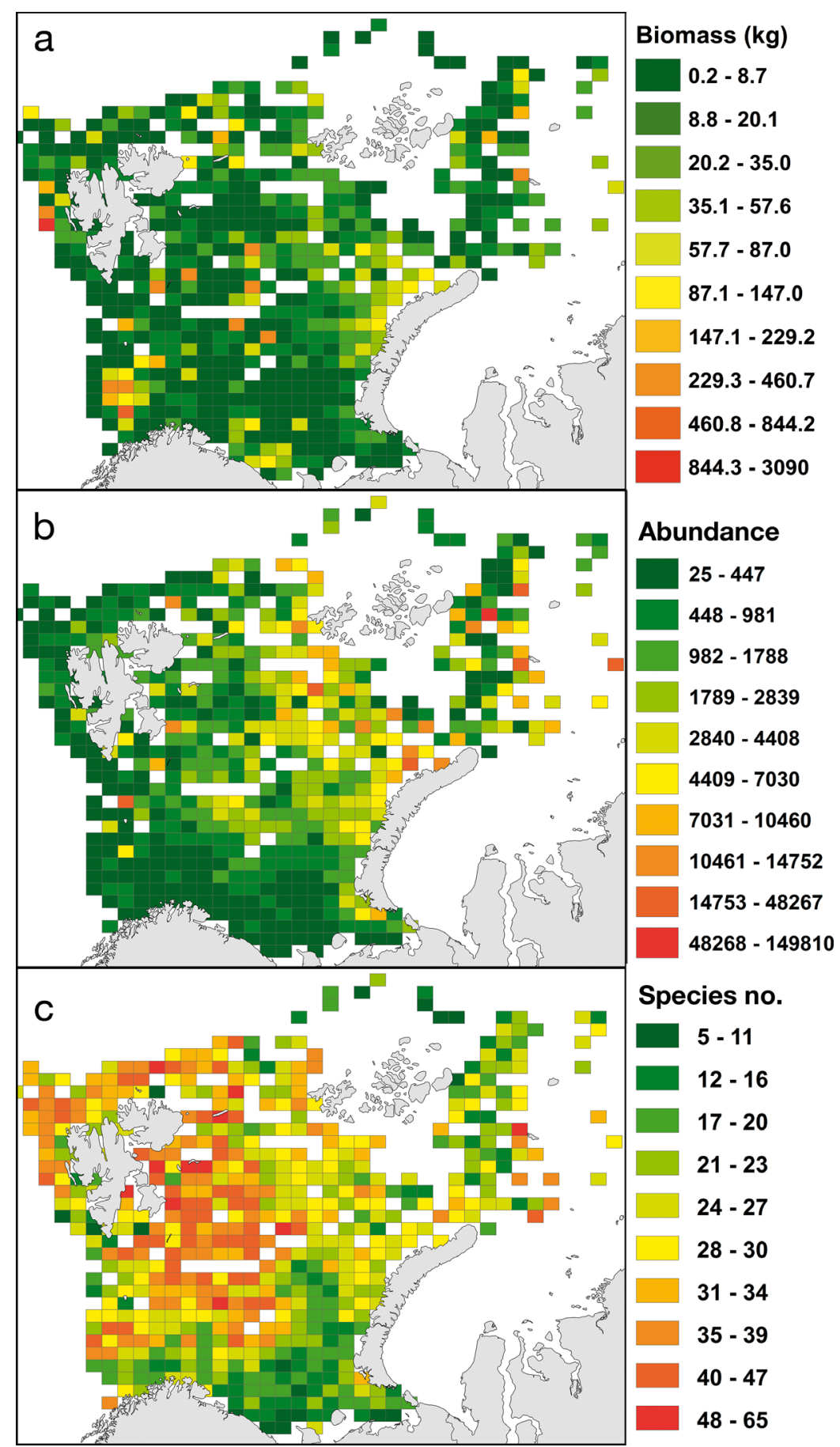

Fig. 2. Barents Sea benthic megafaunal maps, showing (a) biomass (kg per standardized trawl), (b) abundance (individuals per standardized trawl), and (c) species richness (number of species per trawl catch) averaged across 2009-2015 for each grid cell $(36 \times 36$ nautical miles $)$ 


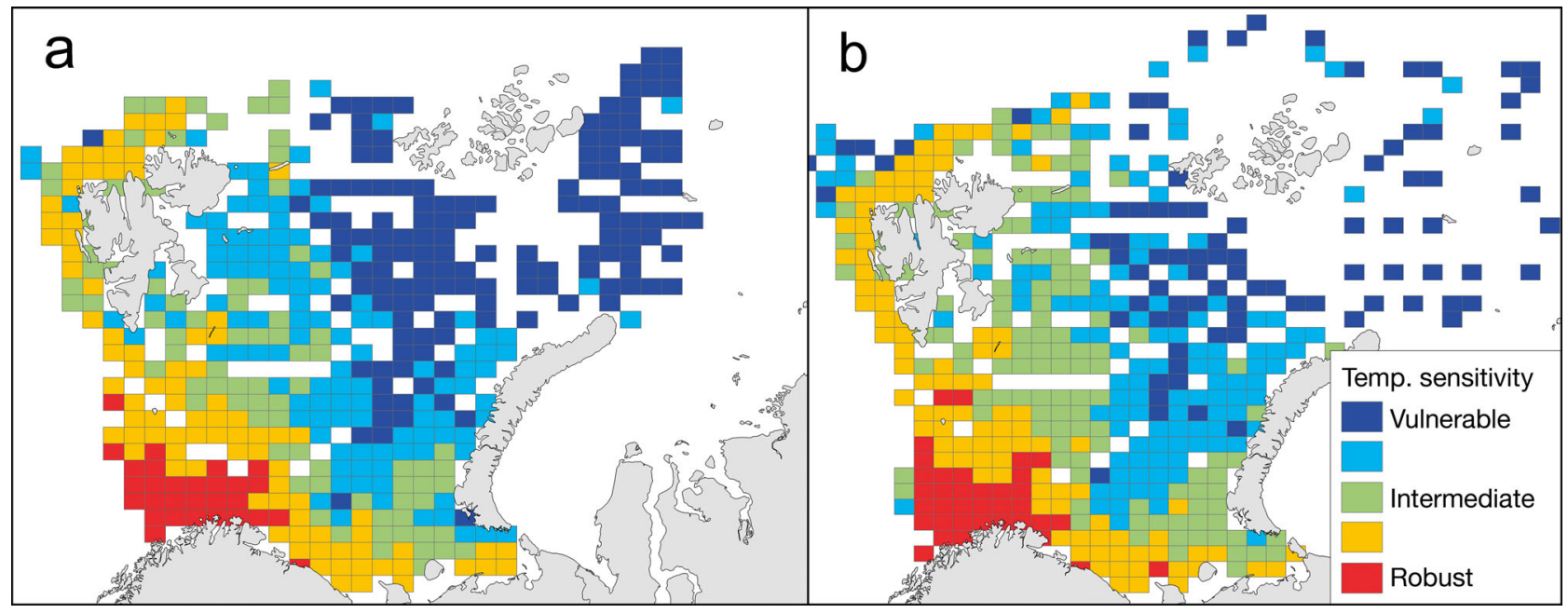

Fig. 3. Temperature sensitivity of benthic communities calculated as the mean of taxa ranks (based on temperature median and range) for (a) 2009-2011 and (b) 2012-2015. Sensitivity is computed for each grid cell (36 × 36 nautical miles) as the average for sampling stations associated with that grid cell across years

locations around Svalbard, in the Bear Island Trench, and on Spitsbergen Bank (Fig. 2b). The number of taxa revealed biodiversity hotspots (Fig. 2c) in the western, central parts of the Barents Sea.

\subsection{Climate change sensitivity}

The boreal communities were associated with areas of warm, year-round ice-free waters in the southwest (Fig. 3), west of Svalbard, and in the southern Barents Sea. The Arctic communities were distributed in the northeast and were associated with Arctic water. Communities found in the transition zone between the areas inhabited by Arctic and boreal communities were characterized by species with wider temperature tolerance ranges relative to those of Arctic communities (Fig. S4.2). The area containing communities with a calculated lower temperature preference was reduced in the central Barents Sea in later years (Fig. S4.1), whereas the transition zone expanded north and east, and communities with higher temperature preference covered the entire shelf area west of Svalbard (Fig. 3).

There was an increased importance of species with warmwater affinity and a reduction in importance of species with coldwater affinity (i.e. community warming) throughout the Barents Sea from the cooler period (2009-2011) to the warmer period (2012-2015) (Fig. 4). The GLS model showed that mean benthos community temperature sensitivity decreased significantly in the Barents Sea from the earlier, cooler period, to the more recent warmer period $(\mathrm{p}=0.0011)$.

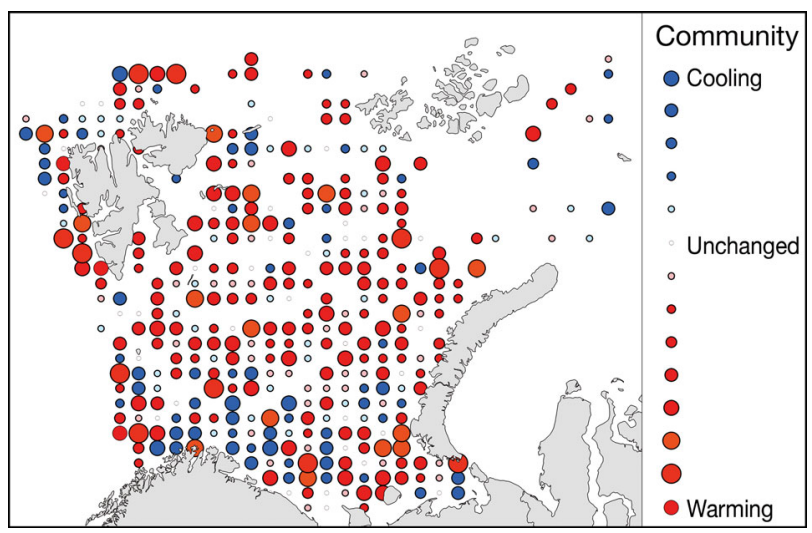

Fig. 4. Hotspots of change between 2012-2015 and 20092011 in temperature sensitivity of benthic communities. A result is given only for grid cells with values in both periods (see Fig. 3). The size of the circles is proportional to the change in community mean rank values between periods (increasing values in red, decreasing values in blue)

\subsection{Trawl vulnerability}

The central part of the Barents Sea was characterized by communities of species with low vulnerability to trawling (i.e. robust communities) (Fig. 5a) due to their low height above the seabed (Fig. S5a), small body size (Fig. S5b), and high mobility (Fig. S5c). Areas characterized by large, immobile species with high vulnerability to trawling surround this central area, with increasing vulnerability toward the outer regions of the Barents Sea. The weighted (biomass) estimates of vulnerability showed a different spatial pattern, with the southern Barents Sea being relatively robust to trawling, due to a dominance of 


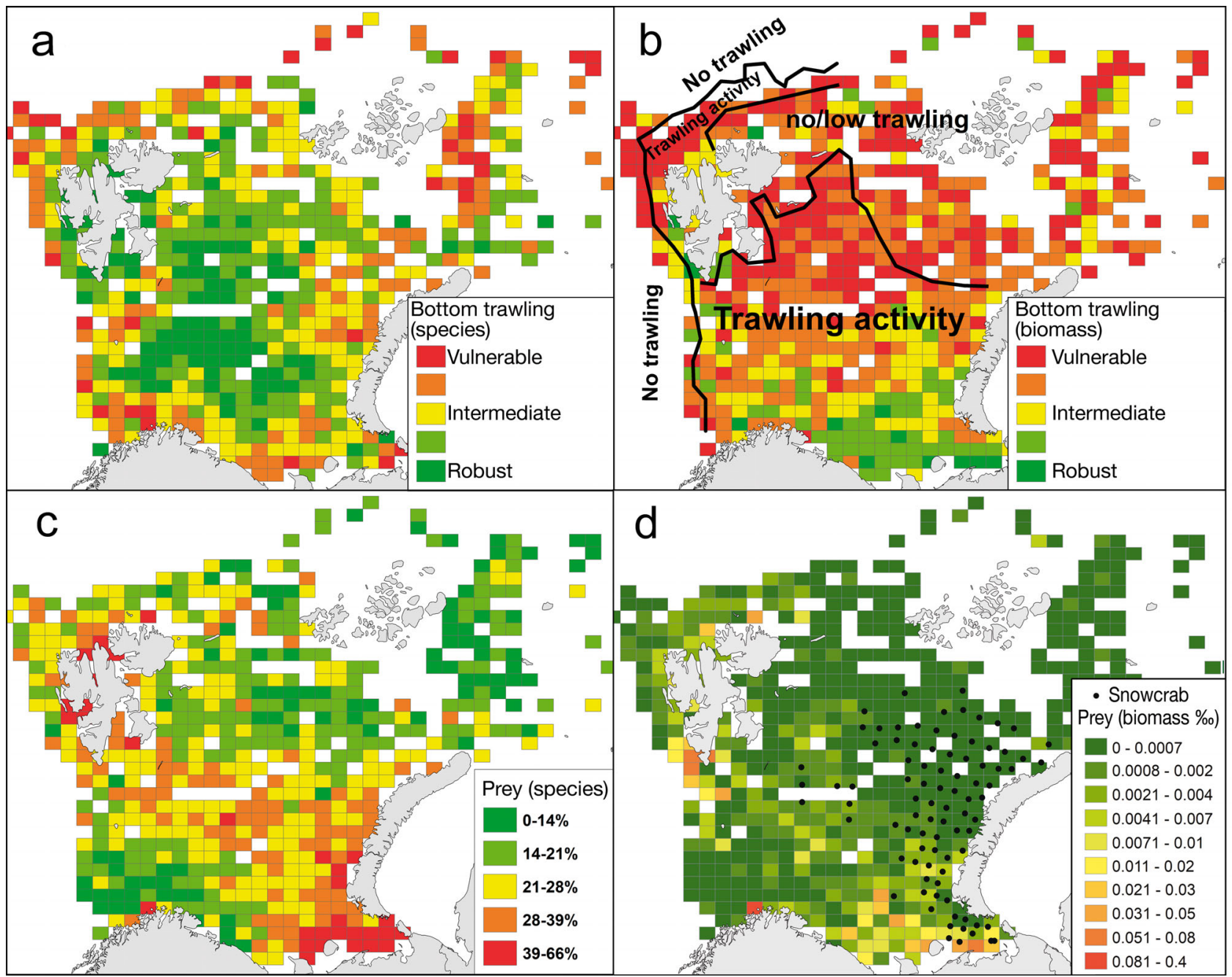

Fig. 5. Barents Sea benthic community vulnerability to $(a, b)$ bottom trawling, based on (a) unweighted (taxonomic composition) and (b) weighted (by biomass) estimates, and to (c,d) snow crab predation, based on the percentage of snow crab prey (c) taxa and (d) biomass in relation to the total number of taxa and total biomass, respectively. Vulnerability is expressed as the average for sampling stations across years calculated for each grid cell (36 × 36 nautical miles)

motile, flat, and/or small species (Fig. S5) and an increase in vulnerability toward the north due to increasing biomass of large, upright species (Fig. 5b).

\subsection{Sensitivity to snow crab predation}

Benthic communities with higher prevalence of snow crab prey species (Fig. 5c) were found along a corridor stretching from Svalbard to the southeastern part of the Barents Sea, whereas communities with fewer prey species prevailed in the southwest and northeast. When the prey species were weighted by biomass (Fig. 5d), the area south of Svalbard and the southeastern Barents Sea had higher sensitivity compared to the rest of the Barents Sea.

\section{DISCUSSION}

We used a trait-based method to show that the temperature sensitivity of the Barents Sea megabenthic communities increases in a northeast direction, but shows a significant overall decrease from an earlier, colder period (2009-2011), to a later, warmer period (2012-2015), indicative of recent poleward expansion of boreal species and a reduction in the importance of Arctic species. Trawling vulnerability is highest in the peripheral areas of the Barents Sea, where large, upright species are prevalent. Sensitivity to snow crab predation is highest along a corridor reaching from the northwest, around Svalbard, to the southeast, where small prey species are most prevalent. Considering 
the geographic distribution of the stressors, climate warming is broadly affecting the Barents Sea, whereas trawling is presently confined to the west, and the snow crab is found primarily in the northeast, but is spreading toward the west. The area east and north Svalbard, with its high richness of coldwater species, consists of large, upright species that are vulnerable to trawling, and of small snow crab prey species; this combination identifies the northwestern area of the Barents Sea as particularly vulnerable.

\subsection{Climate warming}

Megafaunal species recorded with a high mean and a wide temperature range in the Barents Sea, e.g. the sponge Geodia barretti, the sea star Ceramaster granularis, and the sea urchin Spatangus purpureus, can expand in the Barents Sea as long as the living conditions, i.e. depth, substrate, and food availability, are appropriate. Species with a low temperature preference, such as the cephalopod Cirroteuthis muelleri, the decapod Hymenodora glacialis, and the cnidarian sea pen Umbellula encrinus, could decline. Some species are not mobile and must adapt to large temperature fluctuations, e.g. to the large inter-annual variability in water temperature on the shallow banks in the Barents Sea (Årthun et al. 2012). This variability indicates that the August-September temperature used to calculate the temperature sensitivity of each taxon does not fully account for the temperature tolerance of the more than 400 taxa involved in this study. Poleward expansion of boreal megabenthic species has been recognised recently; cephalopod species (Teuthowenia megalops and Todaropsis eblanae) were found in the Arctic Barents Sea for the first time, at distances of more than $2500 \mathrm{~km}$ outside their ranges (Golikov et al. 2013). Early Russian studies reported biomass fluctuations in macrofauna due to climate variability in the Barents Sea (Anisimova et al. 2011), suggesting that a northward displacement of subarctic and temperate species is a response to climate warming in the Arctic (see review by Wassmann et al. 2011). Rates of change in distribution of up to $70 \mathrm{~km}$ per decade have been observed for marine benthic species, but the available evidence of benthic responses to climate change is complex and not yet possible to reliably predict (Birchenough et al. 2015). In the Barents Sea, climate warming has also led to poleward shifts in fish communities (Fossheim et al. 2015).

\subsection{Vulnerability to trawling}

Being a large, long-lived species ( $K$-selection strategies) is a widespread adaptation in polar invertebrates (Clarke 1980) and could explain why some of the large, upright species are so prevalent in the northern areas of the Barents Sea, creating a structurally diverse and complex species habitat. Species included were the basket stars, sea lilies, sponges, sea pens, and cauliflower corals, with upright bodies or arms stretched out in the water to increase prey search volume. Such morphological features (body shapes; see image on p. 1) are easily hit, damaged, and caught/entangled in trawling gear (Jørgensen et al. 2016), and have been reported at reduced densities in trawled areas (Kaiser \& de Groot 2000, Kaiser et al. 2000, Moran \& Stephenson 2000, Pitcher et al. 2000). Trawling has previously been shown to remove epifauna, thereby reducing the complexity and species diversity of the benthic community (Collie et al. 2000). Juvenile fish species are more abundant in areas of complex habitat (Ross et al. 2007); reduced biogenic (e.g. sponges, hydrozoans, bryozoans, amphipod tubes, holothurians, shell aggregates) and sedimentary (e.g. sand waves, depressions) structures may lead to increased predation on juveniles of harvested species and may ultimately reduce recruitment to the harvestable stock (Auster et al. 1996). Although in situ studies of trawling impacts are sparse for the Barents Sea (but see Kutti et al. 2005, Løkkeborg 2005), biomass and species diversity of benthos are commonly negatively correlated with intensity of bottom trawling (Denisenko 2013, Kędra et al. 2013, Buhl-Mortensen et al. 2016, Jørgensen et al. 2016). At least 2 factors must be considered when examining the effects of trawling on benthic populations: the immediate mortality inflicted by trawling gear, and the longer-term ability of populations to cope with this mortality. Such data are developed for many benthic macrofaunal taxa (see Duplisea et al. 2002, Hiddink et al. 2006), whereas for many benthic megafaunal taxa, data are still lacking. In this work, the vulnerability assessment is therefore based on data mainly obtained from the field (height above sediment surface, mean body weight, realised thermal niche).

\subsection{Sensitivity to snow crabs}

Dependent on their sex and size, the diet of snow crabs consists of polychaetes, shrimps, crabs, smaller crustaceans, clams, brittle stars, gastropods, and sea urchins (Squires \& Dawe 2003), and these prey spe- 
cies were common in the southeast, central, and northwestern part of the Barents Sea. With a mean annual consumption rate of less than $5 \mathrm{~g}$ benthic prey per $\mathrm{m}^{2}$ (Manushin et al. 2016) and a temperaturedependent future spread in the Barents Sea (Pavlov \& Sokolov 2003, Bakanev 2015), the first sign of impact on megafauna from the snow crab will be difficult to predict. Furthermore, the proportional community prey biomass in this study may have been low due to the dominant biomass of large-bodied taxa not used as prey. Because the Campelen trawl is a poor sampling device for small taxa, the biomass is therefore only approximate. Combining the results from the trawl with traditional grab sampling would possibly detect a drop in benthic biomass attributed to snow crab predation, as was recorded northwest of Novaya Zemlya (ICES 2017). Reduction in benthic biomass is consistent with a worldwide trend for areas exposed to crab invasions (see Galil et al. 2011).

\subsection{Vulnerability to multiple stressors}

With respect to the geographic distribution of the 3 stressors, climate warming is broadly affecting the Barents Sea, whereas trawling is presently confined to the west, and the snow crab to the northeast. There are indications that species near the edge of their thermal tolerance exhibit stronger responses to climate-related environmental change at stressed sites than at unstressed sites (Hewitt et al. 2016), and that the impact of multiple stressors operating simultaneously results in altered community structure and diversity (Doney et al. 2012). A combination of stressors could therefore result in a rapid reduction in species richness and habitat complexity throughout the Barents Sea.

Climate-driven northward expansion of commercial fish stocks (Kjesbu et al. 2014, Landa et al. 2014, Misund et al. 2016), combined with reduction in perennial sea ice (Årthun et al. 2012), is exposing the seabed to more frequent trawling in the northwest. Combining this increased exposure with the recent records of invasive snow crabs in the west could eventually lead to, or is already resulting in, all 3 stressors affecting the northwestern Barents Sea. This area is characterized by a high diversity of coldwater species with a broad size range, where large-bodied animals, such as sponges, cauliflower corals, sea pens, sea lilies, basket stars, bryozoans, and hydroids, increase the bottom habitat complexity. The bottom trawling mortality of benthic fauna is strongly size-dependent, showing the highest rates for large organisms (Shin et al. 2005), which generally have slow recovery and high catchability (Jennings et al. 2001a,b), e.g. the upright, large-bodied, sessile, coldwater sea pen Umbellula encrinus, whereas the snow crab preys on small-sized individuals (Zakharov et al. 2016). This size-based vulnerability implies that bottom trawling in the northwestern Barents Sea will reduce the largesized benthos in the community and consequently the bottom habitat complexity, and that future expansion of snow crabs into this area will reduce the smallsized benthos in the same community. The communities will thus be exposed to increases in selective mortality at both ends of the size spectrum, while simultaneously experiencing the more general effects of a rapidly warming environment.

This combination of pressures suggests that management (e.g. closed areas, effort management, gear modification) in the northwestern Barents Sea should take steps to limit the effects from bottom trawling and the growing snow crab population inside these species-rich, complex coldwater communities.

Acknowledgements. We acknowledge the joint NorwegianRussian Ecosystem cruise of IMR and PINRO and all colleagues and staff on the ships, in the laboratories, and the offices. We also thank all colleagues within the Norwegian Fishery Directorate, the Norwegian Management plan, the Pan-Arctic Circumpolar Biodiversity Monitoring Plan (Arctic Council), and the ICES secretariat and working groups for their interest in this work and for implementing it into plans and reports. Thanks to the Fram Centre for funding the VULRES project and RCN for funding SI_ARCTIC (228896) and TIBIA (228880), 3 projects that have supported field collections and writing of this manuscript. We thank William King, PhD, from Edanz Group (www.edanzediting. com/ac) for editing a draft of this manuscript, Kirsteen MacKenzie from The Institute of Marine Research (IMR), and Robert McConnaughey from the National Oceanic and Atmospheric Administration (NOAA), and 3 anonymous referees for editing and providing valuable comments.

\section{LITERATURE CITED}

Anisimova NA, Jørgensen LL, Lubin P, Manushin I (2011) Benthos. In: Jakobsen T, Ozhigin V (eds) The Barents Sea ecosystem: Russian-Norwegian cooperation in research and management. Tapir Academic Press, Trondheim, p

Årthun M, Eldevik T, Smedsrud LH, Skagseth Ø, Ingvaldsen RB (2012) Quantifying the influence of Atlantic heat on Barents Sea ice variability and retreat. J Clim 25: 4736-4743

Auster PJ, Malatesta RJ, Langton RW, Watting L and others (1996) The impacts of mobile fishing gear on seafloor habitats in the Gulf of Maine (Northwest Atlantic): implications for conservation of fish populations. Rev Fish Sci 4:185-202

Bakanev SV (2015) Dispersion and assessment of possible distribution of snow crab opilio (Chionoecetes opilio) in 
the Barents Sea. Principy Ekol 2015:27-39 (in Russian)

Bakanev SV, Zhak YE, Pavlov VA (2016) Spatial distribution of the snow crab in the Barents Sea. In: In: Sokolov KM, Strelkova NA, Manushin IE, Sennikov AM (eds) Snow crab Chionoecetes opilio in the Barents and Kara Seas. PINRO Press, Murmansk, p 74-83 (in Russian)

Birchenough SNR, Reiss H, Degraer S, Mieszkowska N and others (2015) Climate change and marine benthos: a review of existing research and future directions in the North Atlantic. Wiley Interdiscip Rev Clim Change 6: 203-223

Buhl-Mortensen L, Ellingsen KE, Buhl-Mortensen P, Skaar KL, Gonzalez-Mirelis G (2016) Trawling disturbance on megabenthos and sediment in the Barents Sea: chronic effects on density, diversity, and composition. ICES J Mar Sci 73(Suppl 1):i98-i114

Certain G, Jørgensen LL, Christel I, Planque B, Vinceny B (2015) Mapping the vulnerability of animal community to pressure in marine systems: disentangling pressure types and integrating their impact from the individual to the community level. ICES J Mar Sci 72:1470-1482

* Cheung WW, Lam VW, Sarmiento JL, Kearney K, Watson R, Pauly D (2009) Projecting global marine biodiversity impacts under climate change scenarios. Fish Fish 10: $235-251$

Clarke AA (1980) A reappraisal of the concept of metabolic cold adaptation in polar marine invertebrates. Biol J Linn Soc 14:77-92

Collie JS, Escanero GA, Valentine PC (2000) Photographic evaluation of the impacts of bottom fishing on benthic epifauna. ICES J Mar Sci 57:987-1001

Crain CM, Kroeker K, Halpern BS (2008) Interactive and cumulative effects of multiple human stressors in marine systems. Ecol Lett 11:1304-1315

Degen R, Jørgensen LL, Ljubin P, Ellingsen IH, Pehlke H, Brey T (2016) Patterns and drivers of megabenthic secondary production on the Barents Sea shelf. Mar Ecol Prog Ser 546:1-16

Denisenko SG (2013) Effect of bottom fishing on zoobenthos. In: Denisenko SG (ed) Biodiversity and bioresources of macrozoobenthos in the Barents Sea. Structure and longterm changes. Nauka, Saint Petersburg, p 2743-2748 (in Russian)

Devictor V, Julliard R, Couvet D, Jiguet F (2008) Birds are tracking climate warming, but not fast enough. Proc R Soc B 275:2743-2748

Doney SC, Ruckelshaus M, Duffy JE, Barry JP and others (2012) Climate change impacts on marine ecosystems. Annu Rev Mar Sci 4:11-37

* Duplisea DE, Jennings S, Warr KJ, Dinmore TA (2002) A size-based model of the impacts of bottom trawling on benthic community structure. Can J Fish Aquat Sci 59: 1785-1795

Engås A, Ona E (1990) Day and night fish distribution pattern in the net mouth area of the Norwegian bottom-sampling trawl. Rapp P-V Reun Cons Int Explor Mer 189:123-127

Fossheim M, Primicerio R, Johannessen E, Ingvaldsen RB, Aschan MM, Dolgov AD (2015) Recent warming leads to a rapid borealization of fish communities in the Arctic. Nat Clim Chang 5:673-677

Frainer A, Primicerio R, Kortsch S, Aune M, Dolgov AV, Fossheim M, Aschan MM (2017) Climate-driven changes in functional biogeography of Arctic marine fish communities. Proc Natl Acad Sci USA 114:12202-12207

Galil BS, Clark PF, Carlton JT (eds) (2011) In the wrong place - alien marine crustaceans: distribution, biology and impacts. Springer Series in Invasion Ecology, Vol 6. Springer, Dordrecht

*Golikov AV, Sabirov RM, Lubin PA, Jørgensen LL (2013) Changes in distribution and range structure of Arctic cephalopods due to climatic changes of the last decades. Biodiversity 14:28-35

*Hansen HSB (2016) Three major challenges in managing non-native sedentary Barents Sea snow crab (Chionoecetes opilio). Mar Policy 71:38-43

*Hewitt JE, Ellis JI, Thrush SF (2016) Multiple stressors, nonlinear effects and the implications of climate change impacts on marine coastal ecosystems. Glob Change Biol 22:2665-2675

Hiddink JG, Jennings S, Kaiser MJ, Queirós AM, Duplisea DE, Piet GJ (2006) Cumulative impacts of seabed trawl disturbance on benthic biomass, production, and species richness in different habitats. Can J Fish Aquat Sci 63: 721-736

*Hoegh-Guldberg O, Bruno JF (2010) The impact of climate change on the world's marine ecosystems. Science 328: 1523-1528

ICES (International Council for the Exploration of the Sea) (2017) Report of the Working Group on the Integrated Assessments of the Barents Sea. WGIBAR 2017 Report 16-18 March 2017. Murmansk, Russia. ICES CM 2017/ SSGIEA:04. ICES, Copenhagen

Jakobsson M, Grantz A, Kristoffersen Y, Macnab R (2004) Bathymetry and physiography of the Arctic Ocean and its constituent seas. In: Stein R, Macdonald RW (eds) The Arctic Ocean organic carbon cycle: present and past. Springer, Berlin, p 1-6

Jennings S, Dinmore TA, Duplisea DE, Warr KJ, Lancaster JE (2001a) Trawling disturbance can modify benthic production processes. J Anim Ecol 70:459-475

Jennings S, Pinnegar JK, Polunin NVC, Warr KJ (2001b) Impacts of trawling disturbance on the trophic structure of benthic invertebrate communities. Mar Ecol Prog Ser 213:127-142

* Johannesen E, Ingvaldsen RB, Bogstad B, Dalpadado P and others (2012) The Barents Sea ecosystem state 19702009: climate fluctuations, human impact and trophic interactions. ICES J Mar Sci 69:880-889

Johannesen E, Jørgensen LL, Fossheim M, Primicerio R and others (2017) Consistent large-scale patterns in community structure of benthos and fish in the Barents Sea. Polar Biol 40:237-246

Jørgensen LL, Ljubin P, Skjoldal HR, Ingvaldsen RB, Anisimova N, Manushin I (2015) Distribution of benthic megafauna in the Barents Sea: baseline for an ecosystem approach to management. ICES J Mar Sci 72:595-613

Jørgensen LL, Planque B, Thangstad TH, Certain G (2016) Vulnerability of megabenthic species to trawling in the Barents Sea. ICES J Mar Sci 73(Suppl 1):i84-i97

Kaiser MJ, de Groot SJ (eds) (2000) Effects of fishing on nontarget species and habitats. Biological, conservation and socio-economic issues. Blackwell Science, Oxford

Kaiser MJ, Ramsay K, Richardson CA, Spence FE, Brand AR (2000) Chronic fishing disturbance has changed shelf sea benthic community structure. J Anim Ecol 69:494-503

Kędra M, Renaud PE, Andrade H, Goszczko I, Ambrose WG (2013) Benthic community structure, diversity, and productivity in the shallow Barents Sea bank (Svalbard Bank). Mar Biol 160:805-819

Kenny AJ, Jenkins C, Wood D, Bolam SG and others (2018) 
Assessing cumulative human activities, pressures, and impacts on North Sea benthic habitats using a biological traits approach. ICES J Mar Sci 75:1080-1092

Kjesbu OS, Bogstad B, Devine JA, Gjøsæeter H, Ingvaldsen R, Nash RDM, Skjaeraasen JE (2014) Synergies between climate and management for Atlantic cod fisheries at high latitudes. Proc Natl Acad Sci USA 111:3478-3483

Kortsch S, Primicerio R, Fossheim M, Dolgov A, Aschan M (2015) Climate change alters the structure of arctic marine foodwebs due to poleward shifts of boreal generalists. Proc R Soc B 282:20151546

Kutti T, Høisæter T, Rapp HT, Humborstad O, Løkkeborg S, Nøttestad L (2005) Immediate effects of experimental otter trawling on a sub-Arctic benthic assemblage inside Bear Island fishery protection zone in the Barents Sea. Am Fish Soc Symp 41:519-528

* Landa CS, Ottersen G, Sundby S, Dingsør GE, Stiansen JE (2014) Recruitment, distribution boundary and habitat temperature of an arcto-boreal gadoid in a climatically changing environment: a case study on Northeast Arctic haddock (Melanogrammus aeglefinus). Fish Oceanogr 23:506-520

Larsen $\mathrm{KMH}$, Gonzalez-Pola C, Fratantoni P, BeszczynskaMöller A, Hughes SL (eds) (2015) ICES report on ocean climate 2015. ICES Coop Res Rep No. 331. ICES, Copenhagen

* Lind S, Ingvaldsen RB (2012) Variability and impacts of Atlantic Water entering the Barents Sea from the north. Deep Sea Res I 62:70-88

Lind S, Ingvaldsen RB, Furevik T (2018) Arctic warming hotspot in the northern Barents Sea linked to declining sea-ice import. Nat Clim Chang 8:634-639

Loeng H (1991) Features of the physical oceanographic conditions of the Barents Sea. Polar Res 10:5-18

Løkkeborg S (2005) Impacts of trawling and scallop dredging on benthic habitats and communities. Fish Tech Pap 472. FAO, Rome

Lyubin PA, Anisimova AA, Manushin IE (2011) Long-term effects on benthos of the use of bottom fishing gears. In: Jakobsen T, Ozhigin VK (eds) The Barents Sea, ecosystem, resources and management: half a century of Russian-Norwegian cooperation. Fagbokforlaget, Bergen, p 768-775

Manushin IE, Pavlov VA, Pinchukov MA, Nosova TV (2016) The snow crab feeding in the Barents and Kara Seas. In: Sokolov KM, Strelkova NA, Manushin IE, Sennikov AM (eds) Snow crab Chionoecetes opilio in the Barents and Kara Seas. PINRO Press, Murmansk, p 125-135 (in Russian)

Marshall DJ, Burgess SC (2015) Deconstructing environmental predictability: seasonality, environmental colour and the biogeography of marine life histories. Ecol Lett 18:174-181

Marshall DJ, Krug PJ, Kupriyanova EK, Byrne M, Emlet RB (2012) The biogeography of marine invertebrate life histories. Annu Rev Ecol Evol Syst 43:97-114

Michalsen K, Dalpadado P, Eriksen E, Gjøsæter H and others (2013) Marine living resources of the Barents Sea ecosystem understanding and monitoring in a climate change perspective. Mar Biol Res 9:932-947

Misund OA, Heggland K, Skogseth R, Falck E and others (2016) Norwegian fisheries in the Svalbard zone since 1980. Regulations, profitability and warming waters

Editorial responsibility: Paul Snelgrove, St. John's, Newfoundland and Labrador, Canada affect landings. Polar Sci 10:312-322

*Moran MJ, Stephenson PC (2000) Effects of otter trawling on macrobenthos and management of demersal scalefish fisheries on the continental shelf of north-western Australia. ICES J Mar Sci 57:510-516

Oziel L, Sirven J, Gascard JC (2016) The Barents Sea frontal zones and water masses variability (1980-2011). Ocean Sci 12:169-184

Pavlov VA, Sokolov AM (2003) On the biology of snow crab Chionoecetes opilio (Fabricius, 1788) in the Barents Sea. In: Sokolov VI (ed) Bottom ecosystems of the Barents Sea. VNIRO Proc 142. VNIRO Publishing, Moscow, p 144-150 (in Russian)

* Pitcher CR, Poiner IR, Hill BJ, Burridge CY (2000) Implications of the effects of trawling on sessile megazoobenthos on a tropical shelf in northeastern Australia. ICES J Mar Sci 57:1359-1368

R Development Core Team (2008) R: a language and environment for statistical computing. Foundation for Statistical Computing, Vienna

Ross PM, Thrush SF, Montgomery JC, Walker JW, Parsons DM (2007) Habitat complexity and predation risk determine juvenile snapper (Pagrus auratus) and goatfish (Upeneichthys lineatus) behaviour and distribution. Mar Freshw Res 58:1144-1151

Shevelev MS, Sunnana K, Gusev EV (2011) History of fisheries and hunting. In: Jakobsen T, Ozhigin VK (eds) The Barents Sea, ecosystem, resources and management: half a century of Russian-Norwegian cooperation. Fagbokforlaget, Bergen, p 495-514

Shin YJ, Rochet MJ, Jennings S, Field JG, Gislason H (2005) Using size-based indicators to evaluate the ecosystem effects of fishing. ICES J Mar Sci 62:384-396

Smedsrud LH, Esau I, Ingvaldsen RB, Eldevik T and others (2013) The role of the Barents Sea in the Arctic climate system. Rev Geophys 51:415-449

* Squires HJ, Dawe EG (2003) Stomach contents of snow crab (Chionoecetes opilio, Decapoda, Brachyura) from the Northeast Newfoundland Shelf. J Northwest Atl Fish Sci $32: 27-38$

Strelkova NA (2016) Acclimatization of the snow crab in the Barents and Kara Seas. In: Sokolov KM, Strelkova NA, Manushin IE, Sennikov AM (eds) Snow crab Chionoecetes opilio in the Barents and Kara Seas. PINRO Press, Murmansk, p 17-34 (in Russian)

* Sunday JM, Bates AE, Dulvy NK (2012) Thermal tolerance and the global redistribution of animals. Nat Clim Chang 2:686-690

*Thuiller W, Lavorel S, Arau'jo MB (2005) Niche properties and geographical extent as predictors of species sensitivity to climate change. Glob Ecol Biogeogr 14:347-357

Walther GR, Post E, Convey P, Menzel A and others (2002) Ecological responses to recent climate change. Nature 416:389-395

*Wassmann P, Duarte CM, Agusti S, Sejr MK (2011) Footprints of climate change in the Arctic marine ecosystem. Glob Change Biol 17:1235-1249

Zakharov DV, Strelkova NA, Lyubin PA, Manushin IE (2016) Macrobenthic communities in the area of the snow crab distribution in the Barents and Kara Seas. In: Sokolov KM, Strelkova NA, Manushin IE, Sennikov AM (eds) Snow crab Chionoecetes opilio in the Barents and Kara Seas. PINRO Press, Murmansk, p 59-73 (in Russian)

Submitted: December 14, 2017; Accepted: October 29, 2018

Proofs received from author(s): November 23, 2018 